\title{
Peter Borza
}

Prešovská univerzita, Gréckokatolícka teologická fakulta

\section{Gréckokatolícki mučeníci z obdobia neslobody 1939-1989}

Priebeh dvadsiateho storočia v strednej Európy poznamenali dva totalitné systémy, ktoré hrubo obmedzovali slobodu obyvatel'stva a potláčali akékol'vek opozičné prejavy. Medzi ne zaradili aj slobodné vyznávanie náboženstva na všetkých úrovniach spoločnosti. Predložená štúdia prezentuje osobnosti gréckokatolíckej cirkvi v strednej Európe s dôrazom na územie bývalého Československa. Jedná sa o osobnosti, ktoré prejavili odpor voči totalitným režimom a za svoje neohrozené postoje priniesli najväčšiu obetu vlastného života, alebo sa vystavili riziku smrti. Niektorých Katolícka cirkev po náležitom procese skúmania vyhlásila za blahoslavených a tým navždy zapísala do pamäte Cirkvi. Medzi prezentovanými osobnostami sú však aj nositelia titulu Spravodliví medzi národmi ocenený štátom Izrael za nezištnú pomoc Židom počas druhej svetovej vojny, ked’že pri záchrane rasovo prenasledovaných riskovali stratu vlastného života a života rodinných príslušníkov. Príspevok je vzhl'adom nato rozdelený na dve časti, pričom prvá prezentuje blahoslavených mučeníkov a druhá časteje venovaná osobnostiam, ktoré svoj život vystavili riziku smrti pri záchrane Židov. 


\section{Blahoslavení mučeníci gréckokatolíckej cirkvi}

Obdobie neslobody 1939-1989

Gréckokatolícki mučeníci pochádzajú najmä z obdobia neslobody, ktoré postihlo našu krajinu v rokoch 1939-1989. Dané obdobie charakterizuje azda najväčší vojnový konflikt v dejinách ludstva a rozsiahle dôsledky totalitných ideológií nacionálneho socializmu a komunizmu, ktoré sa prejavili v úpadku humanizmu, ničení materiálnych hodnôt. Samotnú neúctu k l'udskému životu najzjavnejším spôsobom predstavuje holokaust.

Paradoxom je, že kde sú pošliapavané základné ludské práva, tak o to viac vynikajú nositelia a obrancovia ludskosti. $V$ prostredí Gréckokatolíckej cirkvi v rokoch 1939-1989 o také osobnosti nebola núdza.

Nesloboda sa v stredoeurópskom priestore najdlhšie udomácnila pod kuratelou moci Sovietskeho zväzu a ideológie komunizmu. VČeskoslovensku možno dané obdobie rozdelit do troch fáz.

Prvú v rokoch 1948-1958 charakterizuje teror. Pätdesiate roky sú rokmi zatýkania, väznenia, mučenia, rokmi vel'kých monsterprocesov, ale aj prevratných spoločenských zmien akými bolo nastolenie vlády jednej strany KSČ, prenasledovanie krestanov, násilná kolektivizácia polnohospodárstva, transformácia na plánované hospodárstvo a obdobie pätročníc. Druhá fáza sa vyznačuje pocitom zdanlivej slobody v 60 . rokoch minulého storočia. Do popredia v Komunistickej strane Československa (KSČ) sa dostáva skupina politikov hlásajúcich budovanie socializmu s ludskou tvárou. Obdobie je poznačené všeobecným entuziazmom, nadšením s vedecko-technického pokroku vo svete, dochádza k uvol'neniu cenzúry a prenasledovania krestanov, je obnovená gréckokatolícka cirkev a došlo k nadviazaniu diplomatických rozhovorov s Vatikánom. Tretia - najdlhšia fáza sa spája s mrazivou normalizáciou - konsolidáciou pomerov v prospech KSČ a Sovietskeho zväzu po roku 1968. Po vstupe vojsk Varšavskej zmluvy do Československa nastal na dlhých 20 rokov normalizácia - návrat cenzúry, odstránenie nespolahlivých osôb z dôležitých úradov, špehovanie, udavačstvo a obdobie pokrytectva, ktoré trvalo až po novembrovú revolúciu v roku 1989¹.

${ }^{1}$ Por. R. Letz, Prenasledovanie krestanov na Slovensku v rokoch 1948-1989, [w:] Zločiny komunizmu na Slovensku 1948-1989, Prešov 2001, s. 743. 
Kandidát na blahorečenie redemptorista Ján Ivan Mastiliak v jednom zo svojich listov generálnemu tajomníkovi strany Gustávovi Husákovi z roku 1974 opísal tragickost’ a následky protináboženských postupov v spoločnosti, pričom výstižne charakterizoval atmosféru obdobia normalizácie týmito slovami:

Azda najostrejšie sa pocituje zastrašovanie a diskriminačné d’alekosiahle postihy voči rodičom, detom a príbuzným kvôli tomu, že rodičia chcú využit ústavné právo a vyplnit svoju náboženskú i mravnú povinnost a posielajú deti na vyučovanie náboženstva, do kostola na bohoslužby a k sviatostiam, alebo sami chodia. Podobný útlak sa navodzuje na mladých ludí, ktorí uzatvárajú sobáš aj v kostole. Kvôli tomu sa veriaci občania degradujú na podradných členov spoločnosti, hoci práve oni poctivou prácou a spolahlivostou sú najbezpečnejšími jej nosnými piliermi: Sú vystavený hrozbám a postihom celoživotného dosahu, vylučovaní zo stredoškolského a vysokoškolského vzdelania [hoci ide aj o mimoriadne talenty, ktoré by v budúcnosti znamenali ohromný prínos pre celú spoločnost]', (vylučovaní) z vychovávatel'stva, z administratívy, zo zamestnania, pre ktoré majú kvalifikáciu i osvedčené kvality. To vytvára stresové situácie a atmosféru strachu, veriaci žijú akoby pod tlakom nočnej mory, o to horšej, že to ani nemôžu ani nesmú dat najavo alebo psychicky to odreagovat. Tým trpíi zdravie širokých vrstiev veriaceho obyvatel'stva i pracovná výkonnost', nehovoriac už ani o pocitu neštastia. Okrem toho sa ludia vháňajú do neúprimnosti a krivia sa pri tom alebo lámu charakterovo. V takejto atmosfére prekvitá a podporuje sa sykofanstvo, udavačstvo, donášačstvo, takže rodičia začínajú sa bát aj vlastných trojročných detí2.

\section{Blahoslavený Emilián Kovč - kňaz a mučeník}

Narodil sa 20.08.1884 v rodine gréckokatolíckeho kňaza v obci Kosmač na Halíči. Študoval vo L'vove a teologické vzdelanie nadobudol v Ríme. Roku 1911 prijal sviatost' kňazstva. Ako duchovný pôsobil na rôznych miestach až napokon od roku 1922 sa stal farárom mesta Peremyšlany, kde pôsobil až do svojej mučeníckej smrti 25. marca 1944. Vynikal ako majster slova a bol oblúbeným kazatel'om. Do povedomia veriacich sa zapísal ako ochránca sirôt. V roku 1942 udelil hromadne sviatost̉ krstu 800 Židom. Zatklo ho gestapo a po väznení vo L'vove bol prevezený do koncentráčneho tábora Majdanek, kde ako väzeň č. 2399 zomrel v roku 1944. Blahorečený bol pápežom bl. Jánom Pavlom II. v roku 2001 na Ukrajine³.

\footnotetext{
${ }^{2}$ A. Mandzák, Známy, neznámy. Život a dielo redemptoristu Jána Ivana Mastiliaka (1911-1989), Michalovce 2009, s. 347.

${ }^{3}$ Por. M. Durlák, Blažený mučeník Emilán Kovč, „Slovo“, 2009, nr 18-19, s. 42-43.
} 
Mukačevský biskup blahoslavený Teodor Romža

Narodil sa 14. apríla 1911 v obci Veliky Byčkov na Podkarpatskej Rusi. Študoval v Chuste a teologické vzdelanie nadobudol v Ríme. Sviatost’ kňazstva prijal 25. decembra 1936 v Ríme. Po náhlej smrti mukačevského biskupa Alexandra Stojku bol dňa 24. septembra 1944 vysvätený na biskupa v užhorodskej katedrále. Po skončení II. svetovej vojny Československo odstúpilo Podkarpatskú Rus Sovietskému zväzu a užhorodský biskup sa pre totalitný režim stal nepohodlným. Po neúspešnom atentáte ho agentka NKVD usmrtila v mukačevskej nemocnici smrtiacou injekciou.Zomrel v noci z 31. októbra na 1. novembra 1947. Blahorečený bol pápežom bl. Jánom Pavlom II. v roku 2001 na Ukrajine ${ }^{4}$.

Prešovský biskup blahoslavený Pavol Peter Gojdič

Narodil sa 17. júla 1888 v rodine gréckokatolíckeho kňaza v obci Ruské Pekl'any ned’aleko Prešova. Študoval v Bardejove, Prešove a teologické štúdia absolvoval v Budapešti. Sviatost’ kňazstva prijal 27. augusta 1911 v Prešove. Pôsobil v Sabinove a Prešove. V roku 1922 vstúpil do kláštora sv. Bazila Vel'kého v Mukačeve. Biskupskú chirotóniu prijal 25. marca 1927 v bazilike sv. Klimenta v Ríme.

V januári 1951 bol odsúdený v monsterprocese spolu s biskupmi Vojtaššákom a Buzalkom na doživotie. Zomrel na následky komunistického väzenia v Leopoldove dňa 17. júla 1960. Blahorečený bol pápežom bl. Jánom Pavlom II. v roku 2001 v Ríme ${ }^{5}$.

Život blahoslaveného biskupa Pavla Petra Gojdiča, OSBM sa vyznačuje nevýslovnou láskou k Bohu a l'ud’om. Jeho postoj k životu si zaslúži náš obdiv a nasledovanie. Vždy sa postavil na stranu dobra a hrdinsky čelil zlu, ktoré ohrozovalo jeho samého ako aj veriacich gréckokatolíkov. Vernost’ Bohu a Cirkvi vyjadril pokorným znášaním utrpenia vo väzení a dnes nám ho Cirkev právom ponúka za vzor opravdivého krestanského života.

\footnotetext{
${ }^{4}$ Por. P. László, Blažený Teodor Romža. Život a smrt̉ biskupa - mučeníka, Košice 2011, s. 303.

${ }^{5}$ Por. M. Potáš, Dar lásky, Prešov 2001, s. 379.
} 
Prešovský pomocný biskup blahoslavený Vasil' Hopko

Narodil sa 21. apríla 1904 v Hrabskom blízko Bardejova. Študoval v Bardejove a v Prešove, kde dňa 3. februára 1929 prijal sviatost̉ kňazstva. Pôsobil v Prahe a Prešove. Biskupskú chirotóniu prijal 11. mája 1947 v Prešove. Po tzv. Prešovskom sobore v roku 1950 bol zatknutý a odsúdený na 15 rokov väzenia. Po prepustení v roku 1964 bol internovaný v Oseku v severných Čechách a po obnovení gréckokatolíckej cirkvi pôsobil ako svätiaci biskup do roku 1976, ked’ na následky väzenia zomrel 23. júla 1976. Blahorečený bol pápežom bl. Jánom Pavlom II. v roku 2003 v Bratislave ${ }^{6}$.

Blahoslavený biskup Vasil' Hopko bol neoddelitel'nou súčast’ou Gréckokatolíckej cirkvi. Po boku bl. biskupa P. P. Gojdiča stál na čele biskupstva v jej najtažšom období. Celý jeho život bol poznačený utrpením. Už od útleho detstva bol sirotou, matka ako robotníčka v USA si musela zarábat na každodenný chlieb a on bol vychovávaný u svojich príbuzných. Stal sa kňazom, získal doktorát z teológie. Bol redaktorom, profesorom, špirituálom seminára, profesorom teológie, generálnym vikárom, biskupom a väzňom. Mal skromné a pokorné srdce. V škole modlitby a utrpenia sa naučil byt zhovievavý a láskavý k druhým a pre svoju nezištnost’ si vždy zachoval pokoj srdca. Utrpením vo väzení a hrdinskou vernostou Bohu získal nevädnúci veniec slávy v Božom královstve.

\section{Redemptorista blahoslavený Metod Dominik Trčka, CSsR}

Narodil sa 6. júla 1886 vo Frýdlante nad Ostravicí. Študoval vo FrýdkuMístku a u redemptoristov v Červenke. V roku 1902 vstúpil do Kongregácie Najsvätejšieho vykupitel'a. Sviatost̉ kňazstva prijal 17. júla 1910 v Prahe. Pôsobil v Čechách, vo L'vove a neskôr na Slovensku. Počas barbarskej noci z 13. na 14. apríla 1950 bol umiestnený do internáčneho tábora a v roku 1952 odsúdený na 12 rokov väzenia. Zomrel vo väznici Leopoldov dňa 23. marca 1959. Blahorečený bol pápežom bl. Jánom Pavlom II. v roku 2001 v Ríme7.

\footnotetext{
${ }^{6}$ Por. P. Borza, Blahosalvený Vasil' Hopko, prešovský pomocný biskup (1904-1976), Prešov 2003, s. 95.

${ }^{7}$ Por. A. Mandzák, Metod Dominik Trčka, CSsR. Muž, ktorý si vykoledoval mučenícku smrt', [w:] V. Lagová a kol., Smrt’ za mrežami, Prešov 2006, s. 263-283.
} 


\section{Spravodliví medzi národmi}

V rokoch 1939-1945 v tieni druhej svetovej vojny a ničivých dôsledkov nacionálneho socializmu a komunizmu sa v prostredí gréckokatolíckej cikrvi zrodili osobnosti schopné čelit’ neslobode a nel'udskosti doby aj za cenu svojho života, ktorý položili na oltár vernosti Kristovi a Cirkvi. Gréckokatolícke duchovenstvo na čele so svojím biskupom P. P. Gojdičom nezostalo l'ahostajné k tragédii židovských obyvatel'ov a ich láskou prekypujúce srdcia ich nenechali chladnými pri pohlade na utrpenie blížneho, a tak mnohí ako milosrdní samaritáni sa ujali utečencov prenasledovaných hnedou totalitou. Zachránili ich život, nehl'adiac na vlastnú bezpečnost’ a položili svoje životy za životy týchto utláčaných a prenasledovaných l'udí. Svojimi hrdinskými postojmi zachránili čest národa, ktorý najprv ožobračil a potom poslal desattisíce Židov na istú smrt̉ do koncentračných táborov.

Postoj blahoslaveného biskupa P. P. Gojdiča

k Židom na Slovensku

Blahoslavený biskup Pavol Peter Gojdič - prešovský biskup otvorene kritizoval protižidovské opatrenia režimu Slovenskej republiky, osobne zachránil tri desiatky nám známych Židov. Jeho jasný postoj a aktívny prístup inšpiroval aj d’alších duchovných.

Prenikaniu nacistickej ideológie do spoločenského živato na Slovensku sa podobne ako v iných krajinách nedarilo zabránit’. Zhubný vplyv rasovej neznášanlivosti sa skoro prejavil aj v náboženskom prostredí katolíckeho Slovenska. Terčom útokov sa stalo najmä Židovské obyvatel'stvo, ale negatívne prejavy boli badatel'né aj voči príslušníkom iných národnostných menšín. Samozrejme, že tieto opatrenia vážne ohrozovali nielen jednotlivcov, ale aj celé rodiny ba napokon aj národ ako taký, ked’že rodina je základnou bunkou štátu - spoločnosti. Rodina je aj malou cirkvou a základnou jednotkou cirkvi. Nacizmom ohrozené vrstvy spoločnosti si vyžadovali aj zaujatie jasného postoja zo straný majoritnej Katolíckej cirkvi na Slovensku a prispôsobenie pastoračných postupov nepriaznivej situácii v spoločnosti. V tejto oblasti ako prvý na šírenie zhubnej ideológie reagoval P. P. Gojdič pastierským listom č. 400/1939 zo dňa 25. januára 1939 V liste prvýkrát otvorene informoval duchovenstvo o nacistickej ideológii, ktorá je v priamom rozpore s učením Cirkvi o láske k blížnemu, rovnosti l'udí pred Bohom. 
Upriamil pozornost̉ na zločinnost ideológie pohŕdajúcej človekom kvôli jeho príslušnosti k inému národu alebo rase. Napísal:

Terajší, uvedomelý nacionalista sa nevie spriatelit’s myšlienkou, že každý človek, či je biely alebo čierny, Tatár alebo Turek, je rovnakým stvorením Božím, a preto má rovnaké právo na život a na všetko, čo je mu milé, či už to je [rodná] reč, vzácne zvyky alebo starobylé milé tradície. Nechce uznat', že Stvoritel' netriedil l'udí na skupinu vyvolených a skupinu druhoradých, že Spasitel' sveta za každého zomrel, každého vykúpil a vyzdvihol k dôstojnosti dietata Božieho. [...] Milovat’ svoje, to neznamená nenávidiet’ cudzie, to nedáva nikomu právo robit inému krivdu, škodu, roztrpčovat', ujarmit svojho blížneho.

Vtedy si ešte nikto nevedel predstavit ako sa riešenie židovskej otázky prejaví v praktickom živote. Stupňujúce sa násilie vytvorené právnymi úpravami privádzali Židov do bezvýchodiskových situácií, ked' im neostávalo nič, iba život a aj o ten mali byt’ pripravení v koncentračných táboroch. List je vzácnym dobovým dokumentom o postojoch prešovského biskupa P. P. Gojdiča k nacizmu a zároveň odhal'uje vel'kost̉ jeho krestanskej osobnosti. Upozornenie, ktoré predostrel svojim kňazom korešpondovalo so stanoviskom Svätej stolice vyjadreným v encyklike Mit brennender Sorge 9 .

Prenasledovanie židovského obyvatel'stva a jeho deportácie z územia Slovenska vyvolali oprávnenú kritiku aj zo strany Svätej stolice a katolíckych predstavitel'ov na Slovensku, avšak až v roku 1941. Obavy nad ustanoveniami židovského kódexu zo septembra 1941 vyjadril v nóte K. Sidorovi 12. novembra štátny sekretár L. Maglione. Prípravy a samotný priebeh deportácií Židov sledovala Svätá stolica s neskrývaným nesúhlasom. Jej predstavitelia mnohokrát otvorene vystúpili voči protižidovským opatreniam slovenskej vlády. Aj katolícki biskupi na Slovensku v rokoch druhej svetovej vojny zasahovali v prospech prenasledovaných Židov, a to jednak prostredníctvom memoránd a listov zodpovedným inštitúciám, jednak osobnými intervenciami. 7. októbra 1941 vydali slovenskí biskupi memorandum, v ktorom sa zastávali katolíckych veriacich postihnutých židovským kódexom. Krátko pred realizáciou prvých deportácií v marci 1942 sa biskupi obrátili memorandom na vládu SR, v ktorom sa postavili proti vyvezeniu Židov. Žiadali, aby vláda od svojho zámeru ustúpila a našla riešenie, ktoré by neprotirečilo Božiemu zákonu. Dňa 25. marca 1942 odišiel

${ }^{8}$ Archív Gréckokatolíckeho arcibiskupstva Prešov (AGAP), Prezidiálne spisy, sign. 8, rok 1939. Pastiersky list o rasizme a medzinárodnej situácii č. 400/39. Prešov, 25. januára 1939.

${ }^{9} \mathrm{~S}$ úzkostlivou starostlivostou. O postavení katolíckej Cirkvi v Nemecku, [w:] Encykliky Pia XI, tł. Dr. M. Salatňay, Trnava 1937. 
zo Slovenska prvý transport Židov. V ten istý deň sa deportáciami zaoberala Štátna rada. Len traja jej členovia podporili návrh J. Balka, aby Štátna rada protestovala proti deportáciám. Boli to katolícki kňazi J. Vojtaššák, A. Marsina a J. Pôstényi ${ }^{10}$.

Prešovský biskup P. P. Gojdič sa neuspokojil so spoločnou kritikou deportácii, ale na vzniknutú situáciu reagoval aj osobne, ba prispôsobil tomu aj pastoračné požiadavky doby. Viacerých kňazov inšpiroval svojim osobným príkladom a inštrukciami konat v prospech prenasledovaných. Vel'kú pozornost venoval najslabším členom židovských rodín, ktorými boli deti. Po začiatku transportov v marci 1942 napísal 16. mája 1942 list Apoštolskej nunciatúre na Slovensku, v ktorom tvrdo odsúdil barbarské správanie Hlinkovej gardy voči bezbrannému židovskému obyvatel'stvu. Napísal: „Hlboko nás zarmútili krutosti, ktorých sa dopustili pri deportácií Židov na východnom Slovensku orgány takzvanej Hlinkovej gardy, poverené vykonávaním nariadenia o deportácii neštastného židovského ludu. Barbarstvá páchané na tom biednom lude prevyšujú každú nehumánnost" ". Zároveň v liste požadoval urýchlený zásah Svätej stolice u prezidenta Jozefa Tisa, ktorý sa mal ako katolícky kňaz usilovat' o zastavenie transportov. Zaujímavostou listu je prorocké volanie v situácii ak by sa transporty nedali zastavit:

\begin{abstract}
Keby toto nebolo možné, nech Svätá Stolica ráči vyzvat' vel'adôst. pána prezidenta, aby sa vzdal svojho úradu a odovzdal ho svetskej osobe, nech ódium z uskutočňovania nariadení tzv. „židovského kódexu“ nepadne na hlavu katolíckeho kléru, resp. na celú katolícku cirkev. Ak by si však vyžadovali okolnosti a záujmy cirkvi, ako aj odvrátenie väčšieho zla ohrozujúceho blaho cirkvi, aby vel'adôst. pán prezident Tiso ostal na svojom mieste a vykonával prezidentsky úrad, bolo by potrebné, aby bol nútený vrátit’ sa do svetského stavu, a tým by sa dokázalo, že cirkev rozhodne nesúhlasí s hore spomenutým zaobchádzaním vlády so Židmi ${ }^{11}$.
\end{abstract}

Biskup Gojdič nezostal len pri verejných protestoch, ale v rámci svojich možností sa aj osobne angažoval pri záchrane Židov. Spolu s duchovenstvom preukazovali židovským rodinám hrdinskú pomoc v podobe vydávania pravých aj nepravých krstných listov, ukrývania cenností, zabezpečovania pre-

${ }^{10}$ Por. I. Kamenec, Po stopách tragédie, Bratislava 1991, s. 167.

${ }^{11}$ Burzio, chargé d'affaires v Bratislave, kardinálovi Maglionemu. List biskupa Gojdiča zo 16. mája 1942, zaslaný na adresu chargé d'affaires, [w:] I. Kamenec, V. Prečan, S. Škorvánek, Vatikán a Slovenská republika (1939-1945). Dokumenty, Bratislava 1992, s. 124-125. 
zidentských výnimiek a napokon aj ukrývaním prenasledovaných ${ }^{12}$. Biskup Gojdič, vydal niektorým gréckokatolíckym kňazom poverenie krstił a vydávą pravé alebo aj nepravé krstné listy ${ }^{13}$. Tieto aktivity neostali bez pozornosti bezpečnostných zložiek štátu, a tak v prípade niektorých duchovných sa vykonalo vyšetrovanie, ktoré viedlo $k$ zatknutiu a internácii v Ilave. Medzi vyšetrovaných kňazov patril Peter Dudinský - farár v Ihlanoch, ktorý podla zápisnice z vyšetrovania udelil krst 210 Židom. Istý čas bol zaistený v Ilave ${ }^{14}$. Vyšetrovanie prebehlo aj voči Michalovi Szabatovi - farárovi z Laškoviec ${ }^{15}$. Na oboch boli vznesené obvinenia, že sa týmto konaním obohacovali. Prinajmenšom v prípade Petra Dudinského išlo o falošné obvinenie, ked’že mu za nezištnú záchranu Židov počas holokaustu, bolo v roku 1994 in memoriam udelené vyznamenanie Spravodlivý medzi národmi. Titul Spravodlivý medzi národmi bol v roku 1997 in memoriam udelený aj kňazovi Michalovi Mašlejovi z Olšavice. Osobným zanietením a pomocou farníkov zachránil niekol'ko desiatok prenasledovaných židovských spoluobčanov ${ }^{16}$.

Popri eparchiálnych kňazoch sa do prebiehajúcej pomoci zapojili aj rehol'níci. Redemptoristi v Michalovciach ${ }^{17}$ a reholné sestry Rádu sv. Bazila Vel'kého spravujúce dievčenský internát a sestry Kongregácie služobníc Nepoškvrnenej Panny Márie spravujúce eparchiálny sirotinec v Prešove, ktoré v internáte a sirotinci ukrývali židovské deti ${ }^{18}$.

Biskup Gojdič svojim jasným postojom a aktívnym prístupom ukázal správnu cestu aj duchovenstvu a veriacim ako sa majú zachovat $k$ trpiacim Židom. Pomohol sa zorientovat’ v zložitej dobe. Farárovi Michalovi Mašlejovi, ktorý mal obavu, že poskytnutím úkrytu rasovo prenasledovaným ohrozí bezpečnost’ svojich farníkov, biskup povedal:

\footnotetext{
${ }^{12}$ Por. Archív Ústavu pamäti národa (AÚPN) Bratislava, fond KS ZNB S-ŠTB Košice, inv. č. V-745/2, Teodor Rojkovič.

${ }^{13}$ Por. Svedectva Michala Lukáča - Spitzera zo dňa 06.12.2006, archív autora.

${ }^{14}$ Por. Slovenský národný archív (SNA) Bratislava, fond 209, kr. 934. Gréckokatolícky farár Peter Dudinský v Hodermarku - pokrstenie 210 Židov na gr. kat. Zápisnica zo dňa 30. júna 1944.

${ }^{15}$ Por. Falšované krstné listy. Namiesto mŕtvych vpisoval do matriky Židov, „Slovenská Sloboda“, zo dňa 30. januára 1943, s. 2.

${ }^{16}$ Por. P. Borza, Dejiny gréckokatolíckej cirkvi na Slovensku v období II. svetovej vojny (1939-1945), Prešov 2006, s. 166.

${ }^{17}$ Por. A. Mandzák, Čriepky našich dejín. Židovská otázka v Michalovciach a redemptoristi, „Misionár“, 2008, nr 6, s. 48-54.

${ }^{18}$ Por. Svedectvo Judit Knellerovej zo dňa 05.12.2006 a Marianny Zachovej zo dňa 02.01.2007, archív autora.
} 
pomoc prenasledovaným vyplýva z lásky k blížnemu a preto je tvojou povinnostou podla svojich možností pomáhat a poskytnút úkryt deportáciou ohrozeným Židom ${ }^{19}$.

Hlbokou l'udskostou a hrdinskou obetavostou zachránil tri desiatky nám známych rasovo prenasledovaných osôb. Ide však len o zachránených z okolia Prešova a Spiša, v skutočnosti ich bolo iste viac. Stále nepoznáme zachránených z Michaloviec a Humenného aj ked’ v Michalovciach sa s nimi stretol pred kláštorom otcov redemptoristov v auguste 1942 a povzbudzoval ich aby sa nebáli. ÚŠB o tom informovala, že biskup Gojdič sa bozkával zo Židmi a skutoční veriaci tým boli značne pohoršení. Jedna zo zachránených, Marianna Zachová r. Spitzerová mala v roku 1942, ked' začali transporty, 12 rokov. Spolu so sestrou Zuzanou ich biskup umiestnil do internátu kláštora sestier Bazila Vel'kého a dokonca im umožnil navštevovat gymnázium v Prešove. „Žili sme normálnym životom bez strachu a ohrozenia“ napísala vo svojom svedectve. Do dramatickej situácie sa dostal jej otec Pavel Lukáč - Spitzer, ked' boli spolu s biskupom v meste a Hlinkova garda práve začala chytat Židov. Biskup Gojdič ho pevne objal a tým ochránil pred gardistami. Rodinu Fleischerovú zachránil z transportu, ktorý smeroval do koncentračného tábora. Erika Kleinová r. Fleischerová mala vtedy len pät rokov. K tomuto hrdinskému skutku mu postačilo osvedčenie o krste, ktoré osobne vydal. Zachránená Erika si spomínaný dokument uchovávala až do roku 2006, ked' ho priložila k svojmu svedectvu. Znamenal predsa život pre celú jej rodinu. Židia zachránení biskupom Gojdičom dnes žijú v Kanade, Nemecku, Českej republike a na Slovensku. Jeho postoje a skutky záchrany Židov počas trvania prvej Slovenskej republiky ocenil štát Izrael in memoriam vyznamenaním Spravodlivý medzi národmi, ktoré bolo odovzdané príbuzným a následne Prešovskému arcibiskupovi dňa 27. januára 2008 v Bratislave.

\section{Gréckokatolícky kňaz Michal Mašlej}

Narodil sa 18. januára 1903 v meste Electric v severozápadnom štáte USA Montana. Rodičia sa vrátili na Slovensko. Študoval v Sabinove a Prešove. Sviatost' manželstva uzavrel s Auréliou Bizubovou v roku 1930, manželstvo sa však v roku 1931 rozpadlo. Sviatost’ kňazstva prijal z rúk biskupa Pavla Petra Gojdiča v roku 1930 a za kňazske pôsobisko mu určil farnost̉ Ol'šavica na Spiši. Po nástupe komunizmu musel v roku 1950 farnost’ opustit’, žil u svojho

${ }^{19}$ Svedectvo Andreja Fila zo dňa 20.12.2006, archív autora. 
brata v Šarišských Sokolovciach až do obnovenia gréckokatolíckej cirkvi v roku 1968, ked' sa znova vrátil do Oľšavice. Zomrel dňa 17. marca 1986.

Počas druhej svetovej vojny sa zachoval ako skutočný samaritán. Pomáhal všetkým bez ohl'adu na občiansku či náboženskú príslušnost' - Nemcom, Židom, veriacim aj neveriacim. V noci riskujúc svoj život neváhal íst̉ do niekol'ko kilometrov vzdialeného lesa a cez nemecké hliadky previest', potom nakrmit a ukryt židovskú rodinu s takmer zmrznutým dietatom. Pomoc rasovo prenasledovaným uskutočňoval spolu s veriacimi, pričom sa im podarilo na prelome rokov 1944-1945 zachránit̉ okolo sto Židov. Jeho nezištnú pomoc ho v roku 1997 ocenil štát Izrael udelením vyznamenania in memoriam Spravodliví medzi národmi, ktoré bolo odovzdané príbuzným dňa 18. mája 1999 v Bratislave ${ }^{20}$.

Gréckokatolícky kňaz Jozef Borovský s manželkou Evou

Narodil sa 23. októbra 1906 vo Vel'kom Ruskove (okr. Trebišov). Študoval v Košiciach a v Užhorode. V roku 1934 uzavrel sviatost manželstva s Evou Dudinskou, s ktorou mali šest detí. Prvé z nich však skoro po narodení zomrelo. V tom istom roku mu užhorodský biskup Alexander Stojka udelil v Užhorode sviatost̉ kňazstva a vymenoval ho za administrátora farnosti Latorka na Podkarpatskej Rusi. Vo farnosti pôsobil desat rokov a od roku 1945 v Stankoviach až do roku 1950. Počas komunizmu bol väznený a poslaný do vyhnanstva v Čechách. Koncom 50. rokov sa mohol vrátit do svojho rodiska na Slovensko, kde pracoval v Jednotnom rol'níckom družstve. Zdravotné dôvody mu po roku 1968 nedovolili vrátit’ sa do pastorácie. Zomrel 17.júna 1973.

Počas druhej svetovej vojny spolu s manželkou riskujúc svoje životy, zachránili pred istou smrtou v koncentračnom tábore rodinu Dávida Gesslera. Ich nezištnú pomoc ocenil štát Izrael udelením vyznamenania in memoriam Spravodlivímedzi národmi, ktoré bolo odovzdané príbuzným dňa 27. januára 2010 v Bratislave ${ }^{21}$.

\footnotetext{
${ }^{20}$ Por. J. Babjak, Zostali verní. Osudy gréckokatolíckych kňazov, I. zväzok, Prešov 2009, s. 534-538.

${ }^{21}$ Por. J. Babjak, Zostali verní. Osudy gréckokatolíckych kňazov, I. zväzok, Prešov 2009, s. 337-339. Tiež R. A. Gessler, A Life's Journey: From Shattered Dreams to Serendipity, Tel Aviv 2006, s. 256.
} 


\section{Záver}

Krest̉anská kultúra a duchovné dedičstvo sa v najkrajšej forme prezentuje v postavách mučeníkov a osobností, ktoré neváhajú pre život blížneho nasadit svoj vlastný život. Viedlo ich k tomu presvedčenie o nesmiernej láske Boha k človeku, ktorú teologicky vyjadruje aj najvyššie prikázanie platné pre Židov aj krestanov. „Počuj, Izrael, Pán, naš Boh, je jediný Pán. Milovat budeš Pána, svojho Boha, z celého svojho srdca, z celej svojej duše, z celej svojej mysle a $\mathrm{z}$ celej svojej sily! Po prikázaní lásky $\mathrm{k}$ Bohu následuje prikázanie lásky k blížnemu: Milovat budeš svojho blížneho ako seba samého!" (Mk 12, 29-31).

Gréckokatolíckych mučeníkov spája hlboká duchovnost’ a vzdor nespravodlivým totalitným režimom. Zmysel pre pravdu, slobodu a hlboka ludskost zdobila pôsobenie medzi utláčaným obyvatel'stvom. Viera v zmrtvýchvstalého Ježiša Krista a jeho následovanie ich inšpirovalo ako aj dodávalo odvahu tvárou v tvár hrozbám prenasledovatel'ov. Charakteristickou sa pre nich stala vernost' Bohu a Cirkvi.

\section{Greek Catholic martyrs from period of oppression in 1939-1989}

\section{Summary}

Pass of the twentieth century in Central Europe is marked by two totalitarian systems, which grossly restricted the freedom of people and stifled any opposition speeches. These included the free expression of religion at all levels of society. The presented study deals about the personalities of Greek Catholic Church in Central Europe, with emphasis on the territory of Czechoslovakia. These are individuals who had expressed opposition to the totalitarian regime. They also brought the greatest sacrifice of own life for bold attitude to cruel regime or were exposed to risk of death. Greek Catholic Church has declared blessed some of them after the process of investigation and thus forever entered them in the memory of the Greek Catholic Church. Among the presented figures are the bearers of the title Righteous Among the Nations, award-winning in Israel for unconditional aid to Jews during World War II, as they were risking the loss of his life and lives of family members for saving the racially and religiously persecuted. Given later, the contribution is divided into two parts, the first presents the blessed martyrs, that those who died as martyrs and the second part is devoted to individuals who risked their lives while were exposed to the death for rescuing Jews. 